\title{
SUSTAINABLE TOURISM IN THE ACTIVITIES OF CITY AUTHORITIES. POLAND - CASE STUDY
}

\author{
AgATA NiEMCZYK, ${ }^{1}$ RENATA SEWERYN, ${ }^{2}$ AgnieszKA SMALEC ${ }^{3}$ \\ ${ }^{1}$ Cracow University of Economics, Faculty of Management, POLAND \\ e-mail: agata.niemczyk@uek.krakow.pl \\ ${ }^{2}$ Cracow University of Economics, Faculty of Management, POLAND \\ e-mail: renata.seweryn@uek.krakow.pl \\ ${ }^{3}$ University of Szczecin, Faculty of Management and Economics of Services, POLAND \\ e-mail: agnieszka.smalec@usz.edu.pl; Researcher ID: L-3863-2018
}

\section{RECEIVED \\ ACCEPTED \\ JEL \\ CLASSIFICATION \\ KEYWORDS}

ABSTRACT
10 December 2018

28 December 2018

H79, M31, M38, Q01, Z32

sustainable development, tourism, cities, self-government, survey

Sustainable development is a priority challenge for the contemporary world, just like sustainable tourism. The purpose of this article is to present the activities of self-governments' administration which support sustainable tourism development in selected Polish cities. The hypothese was formulated that the attitude of city authorities in Poland towards sustainable tourism development is not homogenous. The purpose of the article was achieved by subject literature review. The empirical part of the work consists of the primary research carried out in 2017 and 2018 among the units of local governments' administration in Poland. Relevant statistical analyses of primary data were carried out by means of non-parametric tests. The results of the analyses allowed proving the hypothese. It is concluded that the cities do not conduct homogenous sustainable tourism policy. However, the more significant sustainable tourism becomes in the strategies of cities development, the more developed the activities in this area become.

\section{Introduction}

Sustainable development, i.e. the economy which makes use of the resources in more environmentallyfriendly and more competitive way is the priority challenge for the contemporary world. Considering the concept of sustainable development it is pertinent to mention that in the second half of the 19th century philosophy called scientism was born. Its roots may be sought in Cartesian philosophy, according to which intellectual trends are 
based on the axiom presuming the certainty of scientific knowledge. The main rule of scientism was sole and full trust in the science. The idea was to use the science in practice as means of modifying and altering the world for the benefit of mankind. Increasing the standard of living used to be treated as superior value (more: Stacewicz, 1993). Initially, this philosophy was driving the economy, and was the source of development and expansion of western civilization. However, in short time the effects of development processes, which were devastating for i.al. natural environment, cumulated.

A very important document reporting on the condition and threats for nature worldwide was the 1969 report of Secretary-General of the UN, U Thant entitled The problems of human world. It initiated the debate on ecodevelopment. The term ecodevelopment first appeared in 1972 in the documents of Stockholm Conference on "Human environment." It was indicated that natural resources are being depleted, therefore unlimited economic growth cannot be guaranteed. It has become necessary to find the ways of preventing the processes of depletion of non-renewable natural resources, pollution of natural environment, fast growing demographic rate, aggravating split between the prosperity of well-developed countries and the rest of population suffering hunger and malnutrition, and the general volatility of ecosystem, not to mention its degradation in some cases (Płachciak, 2011, p. 231).

Growing ecological, demographic, social and economic problems worldwide contributed to the process of moving away from the Cartesian thought (the concept based on the economic growth) to the philosophy of Aristotle, propagating the holistic recognition of the world, and based on the assumption that the whole is more than the sum of its parts (Kowalczyk, 2010, p. 126). At the end of the 1980s. the use of term ecodevelopment in the subject literature was in decline, giving way to the term sustainable development. The hitherto considerations show that sustainable development means the capability of material development in order to maintain long-term existence of human population on the Earth, while ensuring effective use of natural resources, development that is harmless to the environment and human condition, thus giving the same opportunities to the contemporary and future generations (Rossa, 2008, p. 44). The following should be indicated as paradigms of sustainable development (Pezzey, Toman, 2002, pp. 165-232):

- sustainable development is a type of socio-economic development (performed by a human in favor of another human, that seeks environmental and socio-economic egalitarianism),

- sustainable development is a process integrating all and any activity of a human brought to three dimensions: economic, social and environmental, and less frequently expanded to spatial and institutional (political) dimensions,

- sustainable development means desired living environment and sensible society which implements the concept of intra- and intergenerational order.

In the light of the above considerations, it does not seem surprising that sustainable tourism is the same kind of challenge, i.e. one that does not only aim at minimizing the negative impact of its activities on natural environment and local culture, but also strives for generating profits and increasing employment in local communities. Sustainable tourism development is of particular importance in terms of local problems relating to natural resources of local ecosystems. Among the entities responsible for this kind of undertakings one can find i.al. local governments' administration. Frequently, they work out strategies and take actions which both directly and indirectly support sustainable tourism development, engaging different groups of stakeholders.

The purpose of this article is to present the activities of self-governments' administration (particularly of municipalities) which support sustainable tourism development in Poland. This purpose allowed formulating 
the following hypothese: the attitude of city authorities in Poland towards sustainable tourism development is not homogenous. In connection with the above, three auxiliary hypotheses were identified, indicated in the methodological part.

The purpose of the article was achieved by the subject literature review. The empirical part of the work consists of the primary research carried out in 2017 and 2018 among selected cities in Poland. Relevant statistical analyses on primary data were carried out on the basis of non-parametric tests.

The remainder of this paper has been organized as follows: first, the analysis of the literature on sustainable development and sustainable tourism, next the presentation of selected undertakings performed by local authorities all over the world and in Poland in the area of sustainable tourism. Finally, the significant differences in activities supporting sustainable tourism development in Polish cities have been researched.

\section{Literature Review}

\section{From sustainable development to sustainable tourism}

As mentioned above sustainable development is a term which is not clearly defined and has been evolving. For example, in 1987 R. Goodland and G Ledec defined it as: "... a pattern of social and economic transformations (i.e. 'development') which optimizes the economic and other societal benefits available in the present, without jeopardizing the likely potential for similar benefits in the future" (Goodland, Ledec, 1987, pp. 36-37). In 2000 M. Diesendorf stated that "Sustainable development comprises types of economic and social development which protect and enhance the natural environment and social equity" (Diesendorf, 2000, pp. 19-37). On the other hand, in 2007 P. Dasgupta published his definition according to which "sustainable development" is an economic programme along which average well-being of present and future generations, taken together, does not decline over time" (Dasgupta, 2007, p. 3). As the term became popular, a lot of countries decided to apply the concept on different levels of management (mainly on the level of local government) using it as the basis of actions undertaken by them. In 1992 in Rio de Janeiro during the Earth Summit a Declaration (Agenda 21) was signed. The Agenda defined sustainable development in a set of rules amended by numerous indications that constitute a set of recommendations on protection and shaping human life in order to sustain this development. A part of these rules were adopted by "Poland 2025 - Long-term strategy for sustainable development." (Strategia..., 1999). Sustainable development is one of the three priorities of Europe 2020 strategy. Its superior goal is sustainable improvement of the citizens life. The diversity of factors and determinants of self-governments' development contribute to the fact that the specificity of each municipality/city and their functional relations must be considered (Parysek, 2015, pp. 27-53).

A broad range of understanding of the topic prompted the attempt to measure it. The European Union has repeatedly monitored SD on the lowest level of aggregation of administration units (municipalities). In Poland the construction of sustainable development indicators is mainly in the hands of T. Borys, who developed the first set at the end of 1990s, and the following - ten years later (Borys, 2010). The sets of the following indicators had the most significant impact on the range of Polish research into the construction of the indicator (Borys, 2002):

- Common European Sustainable Development Indicators,

- Urban Audit Indicators,

- Environmental pressure for EU indicators,

- HABITAT Indicators - Agenda,

- Sets of indicators used at local level in EU Member States. 
The indicator module of sustainable development is also developed within the System of Self-governments' Analyses. "It is a system of monitoring local public services carried out at the local level (basically cities). Sustainable development indicators are grouped according to the rule of integrated governance in accordance with so-called three-tier governance model: environmental and spatial, economic, and social (including institutional)" (more Stanny, Czarnecki, 2011). These will be covered by research presented in the further part of this article. The focus on them results from the fact that tourism is included in their set (see Table 1).

Table 1. Areas included in the three governances distinguished in the System of Self-governments' Analyses

\begin{tabular}{rll}
\hline \multicolumn{1}{c}{ Social governance } & \multicolumn{1}{c}{ Economic governance } & \multicolumn{1}{c}{ Environmental and spatial governance } \\
\hline 1. Demography & Municipality's finances & Making planning green \\
2. Education & Entrepreneurship & Nature and landscape protection \\
3. Social welfare & Structure of economic entities & Protection and sustainable development of forests \\
4. Health & Level and structure of employment & Soil protection and waste management \\
5. Public security & Residential construction & Protection of the resources of mines \\
6. Housing & Tourism & Water protection \\
7. Culture, sport and recreation (lifestyle) & Agriculture & Atmospheric protection \\
8. Social participation & Technical infrastructure & Acoustic climate protection \\
9. Activity on job market & The use of materials and raw materials & Renewable Energy \\
10. Institutional and political governance & Availability of goods and services & Biological, chemical, electromagnetic security \\
& & and industrial failure effects prevention \\
\hline
\end{tabular}

Source: Borys (2008).

The assumptions of sustainable development found the reflection in tourism quicker than in other areas of life. What is observed in tourism is both the cause and direct consequences of implementing the concept. The cause is observed because "tourism destroys tourism" - tourism is one of the essential causes of excessive exploitation of non-renewable natural resources, and the consequences - because the areas where tourist attractions had been given protection in accordance with the ecological concept became attractive for the visitors (Jedlińska, 2004, p. 42). The value of sustainable tourism is stressed by the fact that the year 2017 was an International Year of Sustainable Tourism for Development. This aims at supporting the change in policies, business practices and consumer behavior in building a more sustainable tourism sector.

The system of tourism reception covers the processes connected with the pursuit to achieve the objectives of sustainable development and creating a tourism product striving to meet the needs of tourists (Niezgoda, 2006, p. 80). As the elements of shaping the model of tourism compliant with the rules of ecodevelopment the following are listed (Jedlińska, 2004, p. 42): 1) pro-ecological tourism infrastructure and "mild" forms of leisure; 2) economical management of resources; 3) environmentally-friendly ecological economy; 4) green marketing; 5) pro-ecological waste management; 6 ) restoration of primary features of areas and the use of natural building materials; 7) environmentally-friendly farming and forestry; 8) the network of roads compliant with local character and traditions; 9)landscape shaped in compliance with the local character and traditions; 10) ensuring necessary living space for animals, plants, biotopes.

Sustainable tourism is treated in the subject literature as "tourism that takes full account of its current and future economic, social and environmental impacts, addressing the needs of visitors, the industry, the environment 
and host communities" (Aall, 2014, p. 2570). The WTO-OMT defines sustainable tourism as follows: "Sustainable tourism development meets the needs of present tourists and host regions while protecting and enhancing opportunities for the future. It is envisaged as leading to management of all resources in such a way that economic, social and aesthetic needs can be fulfilled while maintaining cultural integrity, essential ecological processes, biological diversity and life support systems" (Cernat, Gourdon, 2012; Scutariu, Nastase, Popescu, 2017, p. 1). As a result it is stated that sustainable tourism is not another form of tourism but specific way of managing tourism, which is supposed to render tourism compliant with the needs and natural resources of the protected area, needs of the local people, and also needs of tourists and tourism sector (Risteski, Kocevski, Arnaudov, 2012). Therefore, what drives sustainable tourism is the achievement of balance and harmony between the three main dimensions: ecological, social and economic, i.e. between the needs and expectations of tourists, local communities and those of natural environment.

The objectives of sustainable tourism are and have to be achieved in the society - economy - environment system, whose internal entities are: inhabitants, enterprises, organizations, external investors, and finally - the tourists themselves. In the field of tourist traffic reception what should be kept is the "balance of the power of triangle" composed of three entities: tourists, hosts of tourist reception area and tourism enterprises. The operation of different entities co-participating in the system of tourism reception requires the use of management procedures and the capability to integrate the operations in order to achieve the objectives of various entities (Niezgoda, 2006).

The inhabitants and both local and self-government authorities act in the capacity of hosts of a given tourism region. High social awareness and participation of local communities in building the state and civil society affect working out a coherent policy and strategy compliant with the concept of sustainable development which takes into account common interests and needs.

Positive attitude of the inhabitants is essential for shaping the tourism offer of a given region, since the community is the element of a given place's attractiveness owing to the tradition, local folklore and cultural identity. It is important to remember, however, that inhabitants as one of the entities of the system of tourism reception need to have the feeling of fulfilment of their own needs. The inhabitants are thus perceived both as the co-creators of the tourism product and the buyers of the area product. The place, therefore, should be assessed not only in terms of the needs of tourists, but also in terms of inhabitants leisure, spending retirement time, settling and place to learn or work (Kotler, Heider, Rein, 1993).

The next essential entity - the power of triangle - are the entrepreneurs. Two aspects are of key importance for them: investment and profitability (Jędrzejczyk, 1995, pp. 35-41). Natural resources are the element of tourist interest. However, without the relevant infrastructure the needs of tourists will not be met. The task of different type economic activities is to use these resources with the aim of making the area more attractive for tourists, but in a sustainable way, i.e. in line with the remaining powers of triangle: tourists themselves and local community (Niezgoda, 2006). In this case both the economic aspect of the activity and sustainable development aspect are of key importance. In market conditions development should be planned with reference to competition. "Adopting the concept of sustainable development requires respecting the objectives connected with maintaining the status quo of the natural environment and social welfare in the pursuit of economic objectives, including enhancement of region competitiveness" (Niezgoda, 2006, p. 83).

The third power of triangle, as mentioned before, is a tourist. The documents of European Union read: "in striving to make tourism develop in a sustainable way, the citizens must become more aware tourists, i.e. tourists 
who generally support sustainable tourism development, [...], seek and receive better information about sustainable tourism, are willing to make sensible decisions regarding shopping and travelling" (Communication from..., 2003, p. 20).

Implementing the concept of sustainable development resulted in the change in the attitude of tourists towards the place of leisure. One may even find the set of "principles of ethics for tourists" referring to tourists per se and all other entities involved in the system of tourism reception. Tourism consumer begins to understand that actions consciously taken (or abandoned) are directly relevant to other spheres of economic and social life.

In the light of the above considerations it is clear that everyone should feel responsible for promoting the rules of sustainable development by taking relevant efforts in this respect, which also refers to city authorities. However, it must be stressed that sustainable development should be given a second thought and planned ahead; it should also include all entities functioning within a given territorial unit.

\section{City and sustainable tourism development}

The activities relating to sustainable tourism are only relevant provided that they are conducted in a holistic way, with the participation of the entities of all sectors and inhabitants, including tourists. Subject literature gives examples on implementation of the rules of sustainable tourism, e.g.: Green Globe-accreditation for tourism entities, Blue Flag campaign for the beaches of Slovenia - the program for increasing the awareness of environmental protection, projects conducted in the South Pacific, Mekong, Vietnam, on the coast of Great Britain, or the projects of city authorities in Whistler, Canada (Harris, Griffin, Williams, 2002). Unquestionably, the European and world leader in sustainable tourism is Norway, which is one of the first countries that has met the standards of sustainable development elaborated by UNWTO. The leaders of quality at the moment are four Norwegian regions: Vega, Trysil, Røros and Lærdal, which were granted certificates of the communes of sustainable development for tourism. It is pertinent to mention other examples in this respect, e.g. Croatia, ${ }^{1}$ and China (Yanga, Ryanc, Zhangb, 2014) or Cuba (Laitamaki et al., 2016).

Similar initiatives have been also implemented in smaller spatial units, i.e. the cities. Sustainable development of the city is mainly associated with shaping certain relations but also seeking certain balance between particular aspects of this development (social, economic, ecological and spatial) than - as reported by Brundtland (Brundtland, 1987) - associated with sustainability of development (Mierzejewska, 2015, p. 6). Planning sustainable development of the municipality is performed by means of many different strategic planning documents, e.g. building development strategies, land use plans or granting permits for the use of natural resources and given locations. There are many different ways of sustaining the development of cities. One of them is taking advantage of tourism function. The European Commission makes it clear that tourism, as a branch of industry, relies mostly on small and medium enterprises, and boosts entrepreneurship to a greater degree than other sectors (Airey, 1997).

\footnotetext{
${ }^{1}$ Tourism in this country is perceived by its inhabitants in an ambivalent way, which is widely described by M. Popiel (2015), and increasingly negative impact of tourism on the environment has initiated intensive implementation of the rules of sustainable tourism. Appropriate model was designed by M. Krstinić-Nižic and D. Drpić (2013), based on the following priorities: creation of clusters for common management and sustainable tourism development; participation of the whole society in tourism life of a given region; reinforcement of local community and tourists empathy; growth of awareness of environmental protection; giving the inhabitants access to education via educational institutions; growth of recognition of the region as responsible and sustainable destination; setting the objective for the local community and reinforcement of their motivation; facilitating access to the funds for responsible and sustainable projects.
} 
Tourism is the source of economic prosperity for many areas of economy. Creating a system of managing the space, which is ecologically determined and multifunctional is possible provided that tourism remains in correlation with other sectors of economy, e.g. farming, forestry, services and industry (Steinecke, 1999). This sector is one of the greatest generators of jobs in the world. Tourism development in the cities is also the opportunity to tap into the neglected or postindustrial areas. Appropriate management and planning compliant with the rules of sustainable development mean positive form of economic activity fostering activization and attractiveness of cities and fulfilling the following functions: integrational, stimulating, coordinating, promotional, controlling and educational (Mika, 2007; Bosacki, 2008).

It is pertinent to mention that one of the priorities of the European Union is sustainable development of high quality tourism sector (quality management in sustainable tourism). One can observe the appearance of phrases describing the new trends in tourism aiming at limiting negative effects in the environment such as: alternative tourism, responsible tourism, discreet tourism, green tourism, appropriate tourism, ecotourism, sustainable tourism, and in Germany and Austria - soft tourism (e.g. Cater, Lowman, 1994; Hannenberg, 1994; Krippendorf, Zimmer, Glauber, 1988; Lindberg, Hawkins, 1993; Whelan, 1991). Each of them promotes family tourism, smaller groups, higher awareness and education of tourists and integration with local communities. The example of applying sustainable tourism are "green events" (sustainable business events) (Smith-Christensen, 2009; Sustainable events..., 2012; Adler, Paliś, 2012). In the business events context, many conferences and conventions have also made great strides in terms of improving their environ mental performance. S.M. Tinnish and S.M. Mangal (2012) cited the 2009 State of the Sustainable Meetings Industry report from Meeting Strategies, which found that over half of all professional meeting planners are focusing on sustainability in their event planning. K. Kotowski (2012) noted that two thirds of meeting planners consider a venue's green initiatives to be important when selecting a meeting venue (Mair, 2014). Sustainable development in terms of tourism development, particularly in the cities, means maintaining cultural identity, keeping certain uniqueness and local colors, which often determine the attractiveness of the place. Amongst the basic goals of tourism development in the cities in terms of sustainable development the following might be listed: improving the quality of life of the inhabitants, fostering local economy, improving the quality of urban space, revaluation of historical legacy and enrichment of the city image (Price, 1992). It is important that the available resources are well-managed and the cooperation between the local units is adequate in terms of respect for local communities and the participants of tourist traffic.

According to the most recent Arcadis Ranking of Polish Sustainable Cities (Ranking polskich..., 2017) carried out in 2017 and assessing 50 cities in three dimensions: social, environmental and economic the best result was achieved by Warsaw (the first place in social and economic dimensions, yet only 44th in environmental dimension); the runner-up was Torun (14th in social dimension, 6th in economic, 8th in environmental), and the third place went to Wrocław (3rd in social dimension, 2nd in economic, and 37th in environmental). The leaders of the ranking were scored high in the area of economy (tourism included - see Table 1) and society. Unfortunately, their score in the area of environment was very low (which means that their activity may have negative impact on the natural environment and health and the quality of their inhabitants' living). The Ranking of Polish Sustainable Cities was based on the synthetic indicator based on a set of specific indicators attributed to one of the three areas of sustainable development. The source of the majority of data was the application named Sustainable Development Indicators - the local module and information from the Local Data Bank and BIP (Public Information Bulletin) are available on GUS (Central Statistical Office) website. The report states that Polish cities are not fully sustainable, and the 
level of their development in this respect in particular areas significantly differs. What is important for sustainable development of the cities is not only larger budget, but also coherent and sustainable vision of development and determination in putting the vision into practice. It may be observed that high results (top ten) were obtained by the cities with the lowest GDP per capita, e.g. Lublin, Rzeszów, Olsztyn. Considering the subject of the article an important aspect analyzed in the ranking is concern for the environment (green urban space, clean air, developed sewage and wastewater system, waste management, biodiversity or low-emission public transport) closely related to the development of tourism in cities. In these terms Bielsko-Biała was ranked first, i.al. in the area of waste management - owing to the implementation of modern solutions of separate collection of waste. This city is one of the most significant tourism centers of the region, i.al. due to its location at the foot of Beskids, numerous tourist trails and the possibility to spend time in an active or passive way. It is noted in this region that local communities (both inhabitants and entrepreneurs) are engaged in environmental and climate issues (e.g. saving energy). An interesting solution in terms of environment is used in Łódź, Krakow and Gliwice, namely woonerfs (urban yards), pocket parks or flower meadows. Another positive example is implementation of Green Budget in the city. Lublin was the first to engage inhabitants in creating green zones.

In the light of the above considerations it may be stated that the awareness grows and the cities are increasingly interested in applying the rules of sustainable development in order to improve the inhabitants' quality of living and streamline many internal processes.

\section{Methodology}

The study conducted with the use of CAWI technique in 2017 and 2018 among the representatives of local authorities in Polish cities was possible thanks to the holistic approach to sustainable tourism reflected in the activities of the city authorities in Poland. The author's questionnaire was sent to different units of territorial self-government - Polish cities (selected mainly due to their presence in the ranking of Polish sustainable cities described above, and their tourist values - tourism strategies). Despite numerous reminders sent to the respondents the number of replies equalled $26 \%$. This may seem poor, but in case of a questionnaire-based study on institutional entities it is enough for drawing conclusions. Moreover, this stands for a good reason to continue the study. After rejecting incorrectly filled in questionnaires 31 entities were qualified for further research, out of which $45.2 \%$ were those that represented big cities, i.e. of the population over 200,000 ( $S_{1}$, so-called experimental group), and $54.8 \%$ - small cities ( $\mathrm{S}_{2}$, so-called control group). Analogical structure indicators were observed in relation to the respondents that included actions for sustainable tourism development (54.8\% - $\mathrm{S}_{1}$ group) in their strategies for tourism development, and those that failed to include such actions $\left(45.2 \%-S_{2}\right.$ group). In the set of cities under study $67.7 \%$ proved that tourism industry existing on their territory is engaged in projects for sustainable tourism development ( $\mathrm{S}_{1}$ group), and $32.3 \%$ never declared such activity ( $\mathrm{S}_{2}$ group).

U Mann-Whitney (Anderson, Sweeney, Williams, 2011, p. 373) test was applied in order to find significant differences in terms of acting on the behalf of sustainable tourism in the cities under study (categorized according to their size, implemented strategy of development with elements of sustainable tourism and actions taken by their tourism industry to support sustainable tourism development). On the basis of obtained results, the following hypothese emerged for confirmation: The approach of municipal authorities in Poland towards sustainable tourism is not homogenous. Three research hypotheses were formulated:

$\mathrm{H} 1 \mathrm{~A}$ : The size of a city diversifies the type of sustainable tourism products that are launched. 
H1B: The objectives of sustainable tourism development significantly differ depending on whether the city strategy of tourism development includes the initiatives which benefit sustainable tourism.

H1C: The engagement of tourism industry in sustainable tourism development differentiates the operations of city authorities supporting this kind of development.

Two statistical hypotheses were formulated: $\mathrm{H}_{0}$ - the approach of municipal authorities to sustainable tourism is the same in $S_{1}$ group of cities as in $S_{2}$ group of cities, and $H_{1}$ - the approach of the authorities in both analyzed types of cities $\left(S_{1}\right.$ and $\left.S_{2}\right)$ differs significantly.

\section{Results and discussion}

The results of the analyses compiled in Table 2 allow coming to the following conclusions:

a) considering the approach to sustainable tourism including the type of products that are introduced in this kind of tourism, small and big cities in most cases do not differ (there was only one significant difference revealed);

b) the largest number of significant differences relating to the approach to sustainable tourism were recorded as dependent on whether the cities include the actions for sustainable tourism in their strategies of tourism development or not.

Table 2. Significant differences in the approach to sustainable tourism revealed between the cities under study

\begin{tabular}{|c|c|c|c|}
\hline Specification & 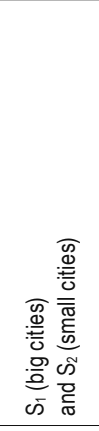 & 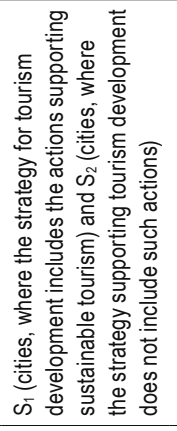 & 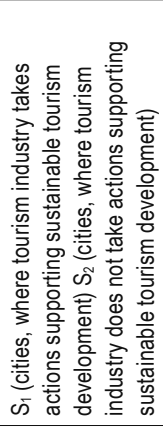 \\
\hline 1 & 2 & 3 & 4 \\
\hline The city records the growth of tourist traffic & 0.101185 & 0.496730 & 1.000000 \\
\hline Modern tourist visiting the city has changed when compared to the past & 0.112233 & 0.698478 & 0.231721 \\
\hline $\begin{array}{l}\text { The strategy for tourism/tourism marketing development in the city includes } \\
\text { the actions for sustainable tourism development }\end{array}$ & 0.513437 & - & 0.062606 \\
\hline \multicolumn{4}{|l|}{ Objectives of sustainable tourism development within tourism policy } \\
\hline - promoting healthy lifestyle in harmony with nature & 0.645322 & 0.000056 & 0.062606 \\
\hline $\begin{array}{l}\text { - bringing people of different nationalities closer, including the promotion of openness and } \\
\text { tolerance }\end{array}$ & 0.271642 & 0.637552 & 0.635724 \\
\hline $\begin{array}{l}\text { - tourism development which shall contribute to preserving natural resources and protection } \\
\text { of traditional culture of local communities }\end{array}$ & 0.645322 & 0.000920 & 0.270249 \\
\hline $\begin{array}{l}\text { - engaging local people already while planning in tourism related actions } \\
\text { in a way that tourism becomes their source of income }\end{array}$ & 0.419436 & 0.001611 & 0.468305 \\
\hline $\begin{array}{l}\text { - aiming at making production and service activities of tourism industry contribute to the } \\
\text { reduction of waste }\end{array}$ & 0.081869 & 0.001385 & 0.153643 \\
\hline $\begin{array}{l}\text { - aiming at making production and service activities of tourism industry contribute to saving } \\
\text { water and energy }\end{array}$ & 0.150949 & 0.000250 & 0.046854 \\
\hline
\end{tabular}




\begin{tabular}{|c|c|c|c|}
\hline 1 & 2 & 3 & 4 \\
\hline $\begin{array}{l}\text { - aiming at making production and service activities of tourism industry contribute } \\
\text { to elimination of the use of substances that are hazardous for environment }\end{array}$ & 0.412262 & 0.060248 & 0.156070 \\
\hline $\begin{array}{l}\text { - aiming at making production and service activities of tourism industry contribute } \\
\text { to motivating staff, customers and local communities to pro-ecological behavior }\end{array}$ & 0.419436 & 0.017705 & 0.468305 \\
\hline $\begin{array}{l}\text { - promotion of free exchange of services in tourism, according to the rules of sustainable } \\
\text { development and respecting international environment protection laws }\end{array}$ & 0.412262 & 0.060248 & 0.156070 \\
\hline - other objectives & 0.827452 & 0.827452 & 0.163837 \\
\hline \multicolumn{4}{|l|}{ Actions taken for sustainable tourism development } \\
\hline - EU projects & 0.131399 & 0.003203 & 0.901678 \\
\hline - advertising campaigns & 0.066996 & 0.066996 & 0.099099 \\
\hline - common initiatives & 0.166514 & 0.024252 & 0.487669 \\
\hline - other & 0.637552 & 0.036271 & 0.027719 \\
\hline Tourism industry in the city takes actions supporting sustainable tourism development & 0.713249 & 0.062606 & - \\
\hline Monitoring of the sustainable tourism development indicators & 0.876026 & 0.197038 & 0.392829 \\
\hline Actions supporting sustainable tourism development brought measurable effects & 0.964516 & 0.003303 & 0.002439 \\
\hline \multicolumn{4}{|l|}{ Sustainable tourism products introduced in the city } \\
\hline - greenways & 0.396469 & 0.051418 & 0.171858 \\
\hline - sightseeing on a bicycle & 0.041110 & 0.546213 & 0.174161 \\
\hline - ecological grocery products in tourism offer & 0.311993 & 0.311993 & 0.153643 \\
\hline - other & 0.337707 & 0.070631 & 0.267818 \\
\hline - none & 0.399417 & 0.299678 & 0.167547 \\
\hline
\end{tabular}

Statistically significant differences were marked in bold.

Source: own research.

What makes small and big cities significantly different in terms of the approach to sustainable tourism is sightseeing on bicycles seen as a product of this type of tourism (Figure 1). As the study shows this form of sightseeing is much more characteristic of big cities. In Poland one can use a very well-developed bike-sharing system, found in the biggest cities and agglomerations. Bicycles are rented for many reasons and purposes, including the visitors renting bikes for sightseeing.

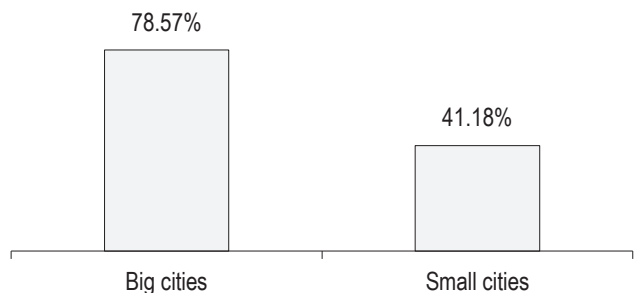

Figure 1. Visiting the city on a bicycle as a sustainable tourism product introduced in the cities under study

Source: own research.

Since the cities under study $\left(S_{1}\right.$ and $\left.S_{2}\right)$ did not differ significantly in terms of introducing other than bicycle sightseeing products of sustainable tourism, the first of sub-hypotheses $(\mathrm{H} 1 \mathrm{~A})$ failed to be empirically confirmed. 
As was observed, considerably more significant differences in terms of the approach to sustainable tourism are dependent on the strategy for tourism development and the question whether it includes the actions for sustainable tourism development or not. These differences refer to both objectives of sustainable development and actions taken, which in fact should not be of any surprise. Considering the objectives, the highest percentage of indications refers to the following issues: promoting healthy lifestyle in harmony with the nature, tourism development which shall contribute to preservation of natural resources and protection of traditional culture of local communities (Figure 2).

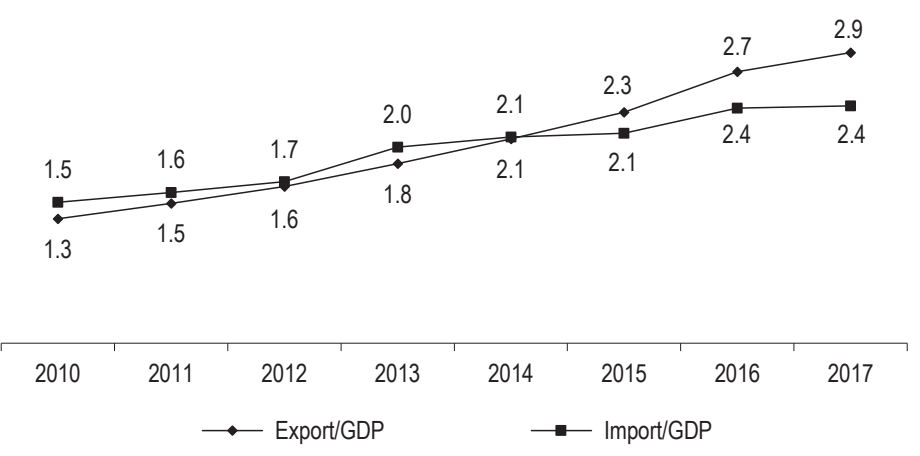

Figure 2. The objectives of sustainable tourism development recognized in the policies of cities under study in reference to their strategy development

Source: own research.

What is important is the fact that none of the studied entities whose strategy for tourism development did not include actions supporting sustainable tourism ( $45.2 \%$ of all respondents) declared a number of objectives which were revealed in the second group of respondents $\left(S_{1}\right)$. It seems justified considering the lack of activity of municipal authorities in this respect in their strategy of development.

Analogically, much more initiatives recognized as EU projects or common initiatives, and other actions supporting sustainable tourism development are taken by those cities whose strategy of development includes elements of sustainable tourism (Figure 3). On the one hand, it is observed that EU projects are characteristic of both groups of respondents (pursuit of cities to obtain EU funds for particular initiatives). On the other hand, common initiatives (e.g. cross-border cooperation for development and promotion of the cities, partnership of the cities, urban campaigns, e.g. Poznań promotes sustainable transport, promotion of equestrian tourism and other) are prevalent in the cities where the strategy of tourism development includes the elements of sustainable tourism - i.e. over seven times higher percentage of indications as compared to the cities whose strategies of development do not include initiatives for sustainable tourism development.

Clearly, the presented results of the research show that as much as $65 \%$ of the cities where the strategy of tourism development includes the actions supporting sustainable tourism development record measurable effects of actions taken in support of sustainable tourism development (Figure 4). Among these effects the respondents indicated the following: more recreational green areas, reduction of car traffic in the city, more children-friendly zones, new areas 
for walking, cycle paths, emergence of aware civil society striving for improving their surroundings, creation of new creative spaces, more domestic and foreign visitors, more waste segregation, development of neglected parts of the city, growth of interest in tourism products in the city, change in the awareness of the inhabitants, increase in the number of accommodation facilities, enhancement of the city image, improvement of cleanness, growth of income in the city, drop in unemployment and creation of new jobs, effective use of EU funds from regional programs.

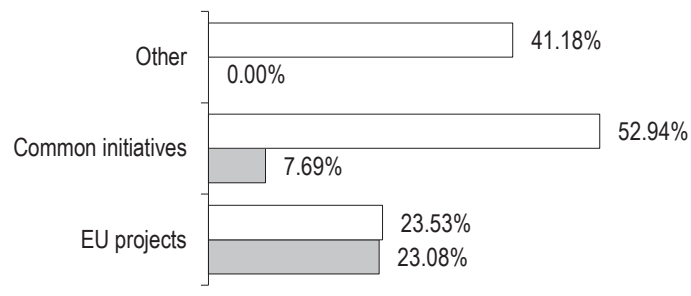

$\square$ The strategy for tourism/tourism marketing development includes the actions supporting sustainable tourism development

$\square$ The strategy for tourism/tourism marketing development does not include the actions supporting sustainable tourism development

Figur 3. The objectives of sustainable tourism development of cities under study in reference to their development strategy Source: own research.

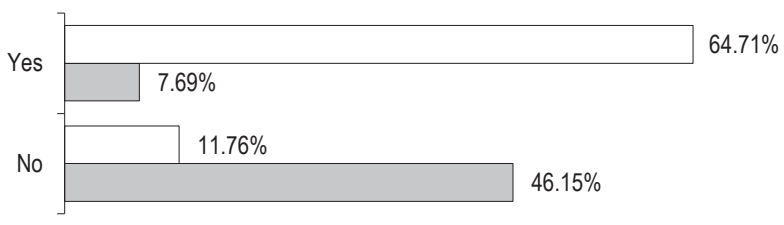

$\square$ The strategy for tourism/tourism marketing development includes the actions supporting sustainable tourism development

$\square$ The strategy for tourism/tourism marketing development does not include the actions supporting sustainable tourism development

Figure 4. Measurable effects of actions supporting sustainable tourism development in the cities under study in reference to their development strategy

Source: own research.

The analysis of empirical data obtained from the study allowed noting that tourism industry and its engagement in sustainable tourism development is a factor significantly differentiating the objectives and actions of cities in this respect. Considering the above the following should be stated:

- in the cities where tourism industry takes actions that support sustainable tourism development, the objective that is frequently included in tourism policies is the pursuit of production and services that are provided in a water-efficient and energy-efficient forms (Table 3); 
- engagement of tourism industry in sustainable tourism development leads to taking actions supporting sustainable tourism other than EU projects, advertising campaigns or common initiatives (Table 3); however, considering the fact that engagement of tourism industry in sustainable tourism development does not significantly determine actions such as EU project, advertising campaigns or common initiatives, the third sub-hypothesis $(\mathrm{H} 1 \mathrm{C})$ cannot be deemed confirmed;

- engagement of tourism industry in sustainable tourism development gives measurable effects in more than a half of the cities under study (see Table 3).

Table 3. Tourism industry activity in terms of sustainable tourism development vs. selected aspects of self-governments' activity for sustainable development and their consequences in the cities under research

\begin{tabular}{l}
\hline \multicolumn{1}{c}{ Aspect } \\
\hline The goal of sustainable tourism development in terms of tourism policy is striving for the production and services \\
activity of tourism industry that are water and energy efficient \\
Undertaking actions by the city's self-government that support sustainable tourism development other than EU \\
projects, marketing campaigns and common initiatives \\
Noticeable and measurable effects of the self-government's actions for sustainable tourism development \\
\hline
\end{tabular}

Source: own research.

\section{Conclusions}

Presented considerations entitle the authors to confirm the main hypothese. Polish cities do not conduct homogenous policies in terms of sustainable tourism. Considering the fact that each city is characteristic in its own way, they take actions that support sustainable tourism according to and matching their specificity. However, it may be observed that the more attention is paid to sustainable tourism in the strategy of development, the more developed these actions become.

The undertakings in the area of sustainable tourism presented in this paper may also be found reasonable in terms of the actions towards the inhabitants. Even if Polish cities, as was indicated, are not fully sustainable (considering all aspects of the phenomena), the actions relating to sustainable tourism are fully legitimate. It is worth considering the implementation of the idea of sustainable tourism in the cities because it seems a solution if the cities wish to overcome the negative effects of expansive development of tourism, e.g. cultural and environmental degradation, commercialization of space. This idea will definitely have impact on the quality of living of the local communities and on socio-economic activation of the cities. The research also shows that the cooperation between many entities is essential, as it may result in creating the opportunity to i.al. use the financial measures in a better way or creation of an educational lobbies to support environment.

Our research here, however, is not without its limitations. The considerations are based on limited number of respondents who, which must be stressed, were willing to participate in the study (the rest did not show interest in this respect); nonetheless a significant part of them were representatives of big cities. For this reason the Authors decided that presented results shall be treated to some extent as pilot study which shall become the basis for further research. As a result the Authors undertake to conduct further works in this respect hoping that more self-governments of the cities will participate (eventually reaching all the cities listed in the Ranking of Polish 
Sustainable Cities, as well as other cities outside the ranking) and their goal will first of all be to show the changes in the subject under study, provided that the action of municipal authorities supporting sustainable tourism will be even more intensified, geared towards the tourist and even more measurable, which has already been established by the Authors as research hypotheses to be reviewed in further research in this respect.

\section{References}

Aall, C. (2014). Sustainable Tourism in Practice: Promoting or Perverting the Quest for a Sustainable Development? Sustainability, 6, 2562-2583.

Adler, D., Paliś, B. (2017). Management of Sustainable Events-Case Studies. In: A. Jaki, B. Mikuła, (eds.), Knowledge Economy Society Management in the face of contemporary challenges and dilemmas. Kraków: Foundation of Cracow University of Economics.

Airey, D. (1997). Turystyka w miejscach wpisanych na Listę Światowego Dziedzictwa Kultury w obliczu przemian ekonomicznych. In: K. Broński, J. Purchla, Z.K. Zuziak (eds.), Miasto historyczne. Potencjał dziedzictwa. Kraków: Międzynarodowe Centrum Kultury.

Anderson, D.R., Sweeney, D.J., Williams T.A. (2011). Statistics for business and economics. Australia South-Western Cengage Learning.

Borys, T. (2002). Wskaźniki rozwoju zrównoważonego. Podstawowe kierunki badań i zastosowań. Ekonomia i Środowisko, 1, 39-59.

Borys, T. (2008). Zaprojektowanie i przetestowanie ram metodologicznych oraz procedury samooceny gmin na podstawie wskaźników zrównoważonego rozwoju w Systemie Analiz Samorządowych (SAS). Raport dla ZMP (Związek Miast Polskich). Jelenia Góra-Poznań.

Borys, T. (2010). Wskaźniki zrównoważonego rozwoju - efektywna forma konkretyzacji nowego paradygmatu rozwoju, Cz. 1. Co chcemy mierzyć? Zielona Planeta, 3 (90), 14-18.

Bosacki, S. (2008). Kreowanie markowych produktów turystycznych a samorządy terytorialne. In: G. Gołembski (ed.), Turystyka jako czynnik wzrostu konkurencyjności regionów w dobie globalizacji. Poznań: Akademia Ekonomiczna w Poznaniu.

Brundtland, G.H. (1987). Our Common Future. WCED. Oxford: Oxford University Press.

Cater, E., Lowman, G. (eds.) (1994). Ecotourism: a sustainable option? New York: Wiley, Chichester.

Cernat, L., Gourdon J. (2012). Paths to success: Benchmarking cross-country Sustainable Tourism. Tourism Management, 33, 1044-1056.

Communication from the Commission to the European Parliament, the Council, the European Economic and Social Committee and the Committee of the Regions on Primary Directions for Sustainable Tourism Development in Europe (2003). Brussels, 24 November.

Dasgupta, P. (2007). Measuring Sustainable Development: Theory and Application. Asian Development Review, 24 (1), 1-10.

Diesendorf, M. (2000). Sustainability and sustainable development, in Dunphy. In: D. Benveniste, J. Griffiths, P. Sutton (eds.), Sustainability: The corporate challenge of the 21st century (pp. 19-37). Sydney: Allen \& Unwin, chap. 2.

Goodland, R., Ledec, G. (1987). Neoclassical Economics and Principles of Sustainable Development. Ecological Modelling, 38, $19-46$.

Hannenberg, P. (ed.) (1994). Tourism and environment. Stockholm: Ecotourism, Enviro.

Harris, R., Griffin, T., Williams, P. (eds). (2002). Sustainable tourism - a global perspective. Oxford: Butterworth-Heinemann.

Jedlińska, M. (2004). Postmodernizm i model trwałej konsumpcji jako przesłanki zmian konsumpcji turystycznej. Problemy Turystyki, $1-2,33-45$.

Jędrzejczyk, I. (1995). Ekologiczne uwarunkowania i funkcje turystyki. Katowice: Śląsk.

Kotler, P., Heider, D.H., Rein I. (1993). Marketing places. New York: The Free Press.

Kotowski, K. (2012). Meeting as a green growth strategy. In: G. Lipman, T. DeLacy, R. Hawkins, S. Vorster, M. Jiang (eds.), Green Growth and Travelism: Letters from Leaders. Woodeaton, Oxford: Goodfellow Publishers.

Kowalczyk, A. (2010). Turystyka zrównoważona. Warszawa: Wydawnictwo Naukowe PWN.

Krippendorf, J., Zimmer, P., Glauber, H. (1988). Für einen anderen Tourismus, Problemen-Perspectiven-Ratschlage. Frankfurt am Main: Fischer Verl.

Krstinić-Nižic, M., Drpić, D. (2013). Model for Sustainable Tourism Development in Croatia. In: Tourism in Southern and Eastern Europe. Conference Proceedings from 2nd International Scientific Conference Tourism in South East Europe 2013. Crisis - a Challenge of Sustainable Tourism Development, 2, 159-173. 
Laitamaki, J., Hechavarría, L.T., Tada, M., Liu, S., Setyady, N., Vatcharasoontorn, N., Zheng, F. (2016). Sustainable Tourism Development Frameworks and Best Practices: Implications for the Cuban Tourism Industry. Managing Global Transitions, 14 (1), 7-29.

Lindberg, K., Hawkins, D.E. (1993). Ecotourism: a guide for planners and managers. North Bennington: Ecotourism Society.

Mair, J. (2014). Greening of Events. In: T. DeLacy, M. Jiang, G. Lipman, S. Vorster (eds.), Green Growth and Travelism: Concept, policy, and practice for sustainable tourism. New York: Routledge.

Mierzejewska, L. (2015). Zrównoważony rozwój miasta - wybrane sposoby pojmowania, koncepcje i modele. Problemy Rozwoju Miast, $3,5-11$.

Mika, M. (2007). Przemiany pod wpływem turystyki na obszarach recepcji turystycznej. In: W. Kurek (ed.), Turystyka. Kraków: Wydawnictwo Naukowe PWN.

Niezgoda, A. (2006). Obszar recepcji turystycznej w warunkach rozwoju zrównoważonego. Poznań: Akademia Ekonomiczna w Poznaniu.

Parysek, J.J. (2015). Miasto w ujęciu systemowym. Ruch Prawniczy, Ekonomiczny i Socjologiczny, 1, $27-53$.

Pezzey, J.C.V., Toman, M.A. (2002). Progress and Problems in the Economics of Sustainability. International Yearbook of Environmental and Resource Economics. 3, 165-232.

Płachciak, A. (2011). Geneza idei rozwoju zrównoważonego. Ekonomia, 5 (17), 231-248.

Popiel, M. (2015). Znaczenie turystyki zrównoważonej w rozwoju społeczno-gospodarczym na przykładzie Chorwacji. Prace Komisji Geografii Przemysłu Polskiego Towarzystwa Geograficznego, 29 (3), 67-82.

Price, M.F. (1992). Patters of the development of tourism in mountain environments. GeoJoournal, $27,1$.

Ranking polskich miast zrównoważonych (2017). Arcadis. Retrieved from: https://www.arcadis.com/pl/polska/perspektywy/ ranking-polskich-miast-zrownowazonych.

Risteski, M., Kocevski, J., Arnaudov K. (2012). Spatial planning and sustainable tourism as basis for developing competitive tourist destinations. Procedia - Social and Behavioral Sciences, 44, 375-386.

Rossa, S.A. (2008). Sustainable Development Handbook. Boca Raton: The Fairmont Press.

Scutariu, A-L., Nastase, C., Popescu, M. (2017). Perspectives of Sustainable Development of Tourism in the North-East Region of Romania. Sustainability, 9 (1), 1-14.

Smith-Christensen, C. (2009). Sustainability as a Concept within Events. In: R. Raj, J. Musgrave (eds.), Event Management and Sustainability, London: Cab International.

Stacewicz, J. (1993). Pomiędzy społeczeństwem ekonomicznym i ekologicznym. Poznań: PAN.

Stanny, M., Czarnecki, A. (2011). Zrównoważony rozwój obszarów wiejskich Zielonych Płuc Polski. Próba analizy empirycznej. Warszawa: Instytut Rozwoju Wsi i Rolnictwa Polskiej Akademii Nauk.

Steinecke, A. (1999). Turystyka w miastach historycznych: szansa i ryzyko. Spojrzenie niemieckie. In: J. Purchla (ed.), Dziedzictwo a turystyka. Kraków: Międzynarodowe Centrum Kultury.

Strategia zrównoważonego rozwoju Polski do roku 2025 (1999). Ministerstwo Środowiska. Retrieved from: http://snep.edu.pl/sms/ materialy/strategia\%20zrownowazonego\%20rozwoju\%20polski\%20do\%20roku\%202025.pdf.

Sustainable events with ISO 20121 (2012). Geneve: International Organization for Standardization.

Tinnish, S.M., Mangal, S.M. (2012). Sustainable Event Marketing in the MICE Industry: A Theoretical Framework. Journal of Convention \& Event Tourism, 13 (4), 227-249.

Whelan, T. (1991). Nature tourism: managing for the environment. Washington: Island Press.

Yanga, J., Ryanc, Ch., Zhangb, L. (2014). Sustaining culture and seeking a Just Destination: governments, power and tension-a life-cycle approach toanalysingtourism developmentinanethnic-inhabitedscenicareainXinjiang, China. JournalofSustainable Tourism(PDF Download Available). Retrieved from: https://www.researchgate.net/publication/265168131_Journal_of_Sustainable_Tourism.

Cite this article aS: Niemczyk, A., Seweryn, R., Smalec, A. (2018). Sustainable tourism in the activities of city authorities. Poland - case study. European Journal of Service Management, 4 (28/2), 283-297. DOI: 10.18276/ejsm.2018.28/2-35. 